\title{
Prevalence of Nepoviruses in Strawberry and their Serological Detection
}

\author{
Abhilasha Sharma ${ }^{1 *}$, Anil Handa ${ }^{1}$, Bunty Shylla ${ }^{2}$, K.K. Pramanick ${ }^{3}$, \\ Shelly Kapoor ${ }^{1}$ and Shalini Verma ${ }^{1}$ \\ ${ }^{1}$ Department of Plant Pathology, YSPUHF, Nauni, Solan-173230 (H.P), India \\ ${ }^{2}$ Krishi Vigyan Kendra Kandaghat-173215 (H.P), India \\ ${ }^{3}$ IARI Regional Station, Shimla-171004 (H.P), India \\ *Corresponding author
}

\section{A B S T R A C T}

Keywords

ELISA, Strawberry,

Nepoviruses

Article Info

Accepted:

04 February 2018

Available Online:

10 March 2018
Viruses pose a serious threat to strawberry cultivation all over the world as infections resulting from viruses and related pathogens are limiting factors in the production of certified planting material in strawberry. In Himachal Pradesh, strawberry is fast emerging as a short duration fruit crop yielding lucrative returns. Viruses, however, have emerged as a major hindrance in its commercial cultivation. Direct antigen coating (DAC)-ELISA was performed in major commercial cultivars of strawberry to assess the presence of nematode transmitted nepoviruses in these cultivars as the infected plants developed typical ringspots on leaves, the most striking symptom of nepoviruses. DAC-ELISA resulted in the positive reaction against antibodies of nepoviruses thereby confirming the possible association of nepoviruses in the symptomatic plants. Further, double antibody sandwich (DAS)-ELISA was performed to identify the specific nepoviruses associated with infected strawberry plants. Results obtained in DAS-ELISA established the positive association in the three nepoviruses namely Strawberry Latent Ringspot Virus (SLRSV), Tobacco Ringspot Virus (TRSV) and Raspberry Ringspot Virus (RRSV) in the infected plants. These studies will help in the production of virus indexed planting material of strawberry for developing a sound certification programme in this commercially important crop.

\section{Introduction}

Strawberry (Fragaria sp.) is one of the most economically important soft berry fruit. It is an important commercial fruit grown in different parts of the world with a great potential for export if raised from desirable virus indexed mother plants for increasing production and maintaining quality. In India, strawberry is cultivated commercially in the states of Jammu and Kashmir, Himachal
Pradesh, Maharashtra, West Bengal, Nilgiri Hills in TamilNadu, Haryana, Punjab and some parts of Delhi (Anonymous, 2017). In Himachal Pradesh, it is grown largely in the districts of Sirmaur and Solan (Anonymous, 2017). Many viruses pose a major threat to strawberry industry. Out of these viruses, SLRSV, TRSV and RRSV, all members of the genus Nepovirus, are a limiting constraint. Viruses transmitted by nematodes in strawberry have a wide host range and can 
cause significant losses especially when present in mixed infection with other viruses.

SLRSV is locally dispersed by nematode Xiphenema diversicaudatum (EPPO/CABI, 1996) whereas, transmission of TRSV is by nematode vector Xiphenema americanum and the virus is lost by the vector during molting. The third virus RRSV is transmitted by Longidorus sp. Diseases caused by nepoviruses have long been recognized as a limiting factor in the cultivation of several important crops including peach, cherry, tobacco, tomato, blueberry, strawberry and grapevine. Symptoms of nepoviruses in strawberry include mottling, patchy and reddish leaves, necrotic spots, chlorotic ringspot and vein banding (Belli et al., 1980).

\section{Materials and Methods}

\section{Planting material}

Leaves from strawberry cv. Chandler with virus like symptoms were collected in 2016 and 2017 from HRTS \& KVK kandaghat, Solan and IARI Regional Station Dhanda Farm, Shimla.

\section{ELISA detection}

DAC (Direct Antigen Coating) and DAS (Double Antibody Sandwich) forms of ELISA were used for the detection of viruses in the test samples.

\section{DAS-ELISA}

Infected leaves showing symptoms of necrotic spots and vein bending were collected and brought to the laboratory in ice bucket for conducting DAS-ELISA tests as per the protocol given by Clark and Adams (1977). Wells of the microtitre plate (BIOREBA, Switzerland certified microplates) except those of the top and bottom rows and rows on the extreme left and right, were filled with
$200 \mu 1$ aliquots of coating antibodies diluted in $1 \mathrm{x}$ coating buffer $(1: 1000$ ratio $\mathrm{v} / \mathrm{v})$. The plate was incubated in humid box for 4 hours at $30^{\circ}$ C. The coating antibody suspension was removed by shaking out the plate over the wash basin. The wells were filled with $1 \mathrm{x}$ PBS-Tween and kept for 2 minutes with gentle shaking. The plate was emptied and filled again with PBS-Tween. The washing was repeated three times. The test samples were grounded in $1 \mathrm{x}$ extraction buffer (1:10 ratio v/v). All coated wells were filled with $200 \mu \mathrm{l}$ aliquots of test samples (each sample in duplicate) besides positive and negative control wells. The plate was incubated in humid box overnight at $4 \pm 1^{\circ} \mathrm{C}$. The washing steps were repeated as mentioned above. Alkaline phosphate (ALP) conjugated antibodies were filled in each well with $200 \mu \mathrm{l}$ aliquots after diluting it in 1x ECI (enzyme conjugated immunoglobin) buffer at a (ratio of $1: 1000 \mathrm{v} / \mathrm{v})$.

The plate was incubated in humid box for 5 hours at $30^{\circ} \mathrm{C}$. The washing was done as mentioned above. p-nitrophenyl phosphate (pNPP) substrate was dissolved in 1x substrate buffer by dissolving $5 \mathrm{mg}$ pNPP tablet in $5 \mathrm{ml}$ of $1 \mathrm{x}$ substrate buffer. Each well was filled with $200 \mu \mathrm{l}$ aliquots of the substrate.

The plate was kept in humid box in the dark condition at room temperature until a yellow colour was clearly visible in the positive control (usually between 30-60 minutes). The results were assessed either by visual observations or by measurement of the absorbance value of the hydrolysed substrate (p-nitrophenyl) at $405 \mathrm{~nm}$ wavelength in a microtitre plate reader (Micro Scan MS 5605A, Electronics Corporation of India Limited, Hyderabad). The results of ELISA for the detection were interpreted as per Dijkstra and Jager (1998) as samples were considered infected when their absorbance values $\left(\mathrm{A}_{405 \mathrm{~nm}}\right)$ exceeded two times the mean values of respective healthy control samples. 


\section{DAC-ELISA}

In case of DAC-ELISA, the modified procedure given by Handa and Bhardwaj (1994) was followed. Wells of the microtitre plate (NUNC maxisorp certified micro plates) except those of the top and bottom rows and rows on the extreme left and right, were filled with $100 \mu \mathrm{l}$ aliquots of infected sap (each sample in duplicate) diluted in $1 \mathrm{X}$ extraction buffer (1: 10 ratio $\mathrm{w} / \mathrm{v}$ ) besides positive and negative control wells.

The plate was incubated in humid box for 2 hours at $37^{\circ} \mathrm{C}$. The contents of the plate were removed by shaking out the plate over the washbasin.

The wells were filled with 1X PBS-Tween and kept for 2 minutes with gentle shaking. The plate was emptied and filled again with PBSTween.

The washing was repeated three times. The coating antibodies were diluted in $1 \mathrm{X}$ coating buffer (1:500 ratio $\mathrm{v} / \mathrm{v})$. The wells were filled with $100 \mu \mathrm{l}$ aliquots of antibodies. The plates were incubated for 2 hours at $37^{\circ} \mathrm{C}$. The washing steps were repeated as mentioned above.

The alkaline phosphatase (ALP) conjugated goat-antirabbit $\operatorname{IgG}$ were filled in each well with $100 \mu 1$ aliquots after diluting it in $1 \mathrm{X}$ ECI (enzyme conjugated immunoglobin) buffer at a ratio of 1: $200(\mathrm{v} / \mathrm{v})$.

The plates were incubated in humid box for 90 minutes at $37^{\circ} \mathrm{C}$. Washing was done as mentioned above. The p-nitrophenyl phosphate (pNPP) substrate was dissolved in $1 \mathrm{X}$ substrate buffer by dissolving $5 \mathrm{mg}$ pNPP tablet in $5 \mathrm{ml}$ of $1 \mathrm{X}$ substrate buffer.

Each well was filled with $100 \mu \mathrm{l}$ aliquots of substrate. The plates were kept in humid box in the dark condition at room temperature until a yellow colour was clearly visible in the positive control (usually between 30 minutes to 60 minutes). If desired, the reaction was stopped by adding $50 \mu \mathrm{l}$ of $3 \mathrm{M} \mathrm{NaOH}$ to each well.

The results were assessed by measurement of the absorbance value of the hydrolysed substrate (p-nitrophenyl) at $405 \mathrm{~nm}$ wavelength in a microtitre plate reader (Micro Scan MS 5608A, Electronics Corporation of India Limited, Hyderabad).

The results of ELISA for the detection were interpreted as per Dijkstra and Jager (1998) as samples were considered infected when their absorbance values $\left(\mathrm{A}_{405} \mathrm{~nm}\right)$ exceeded two times the mean value of respective healthy control samples.

\section{Results and Discussion}

Data set out in Table 1 indicate the presence of two viruses in strawberry leaves from Dhanda research station. OD value recorded for DAC-ELISA depict that Dhanda samples had the highest value for the two viruses $(0.295$ for SLRSV and 0.376 for TRSV) whereas RRSV was found to present below the detectable limits in DAC-ELISA.

Data based on O.D. values presented in Table 2 indicate the presence of all three nematode transmitted viruses in strawberry leaves from Kandaghat and Nauni. OD values recorded in DAS-ELISA depict that Kandaghat sample had the highest OD value for all the three viruses viz., 0.632 for SLRSV, 0.580 for TRSV and 0.322 for RRSV. All these viruses were detected in DAS-ELISA tests at Kandaghat, Nauni and Dhanda except for RRSV which was not detected at Dhanda farm thereby indicating the strawberry plants at Dhanda farm were free from the infection of RRSV. 
Fig.1 Symptoms exhibited by the nepoviruses
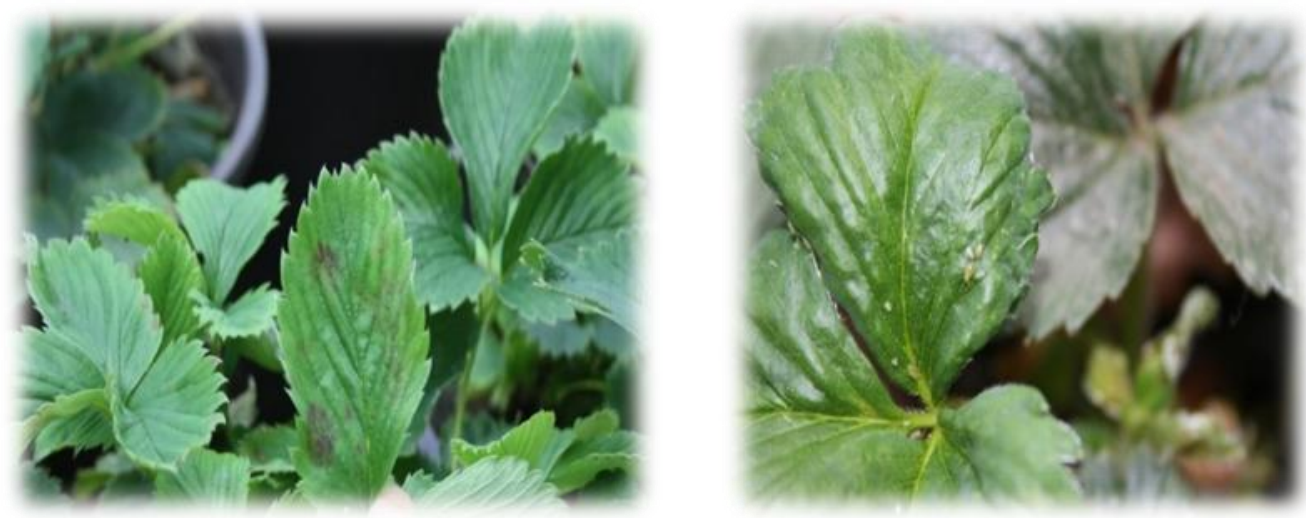

Fig.2 DAC-ELISA plate showing positive reactions with SLRSV, TRSV \& RRSV

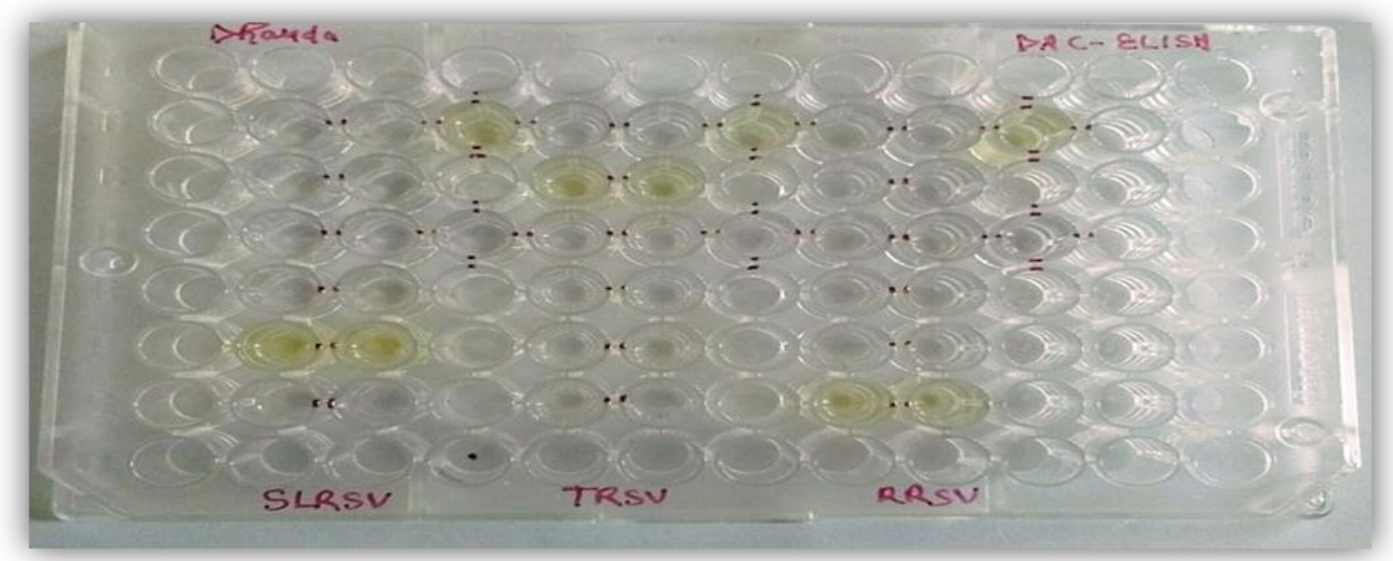

Fig.3 DAS-ELISA plate showing positive reaction with SLRSV, TRSV and RRSV

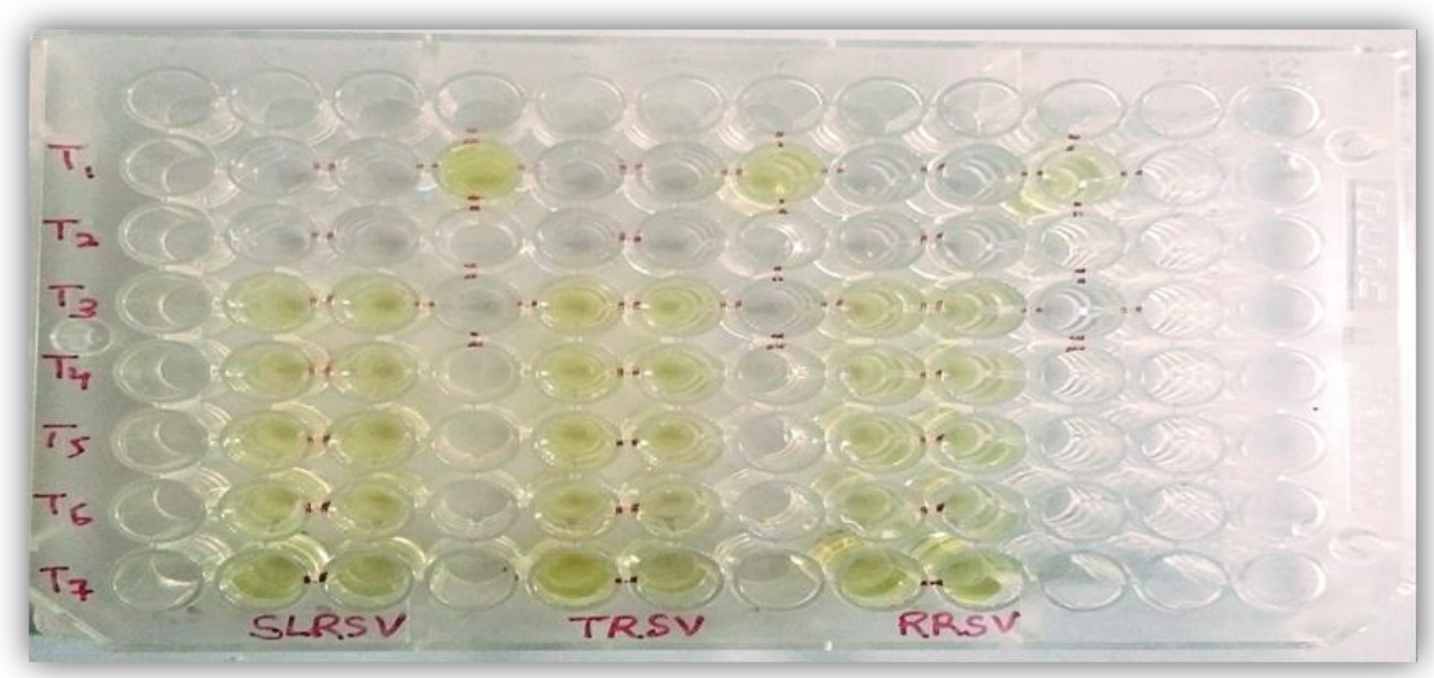


Table.1 DAC-ELISA detection for nepoviruses
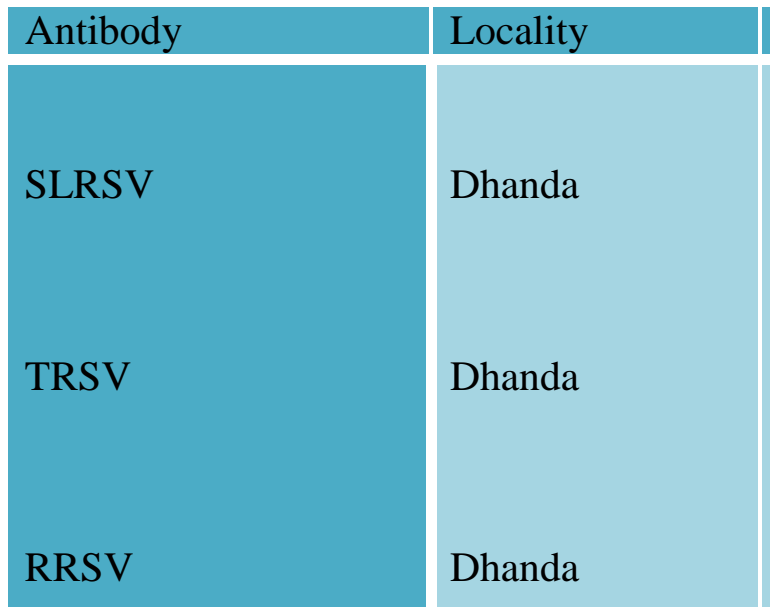

Mean OD value(at $405 \mathrm{~nm})$
\begin{tabular}{|l|l|l|}
\hline $\begin{array}{l}\text { Test } \\
\text { sample }\end{array}$ & $\begin{array}{l}\text { Positive } \\
\text { control }\end{array}$ & $\begin{array}{l}\text { Negative } \\
\text { control }\end{array}$ \\
\hline $0.295(+)$ & $0.248(+)$ & $0.055(-)$ \\
\hline \multicolumn{4}{|l|}{$\begin{array}{l}\text { Test } \\
\text { sample }\end{array}$} & $\begin{array}{l}\text { Positive } \\
\text { control }\end{array}$ & $\begin{array}{l}\text { Negative } \\
\text { control }\end{array}$ \\
\hline $0.376(+)$ & $0.341(+)$ & $0.036(-)$ \\
\hline $\begin{array}{l}\text { Test } \\
\text { sample }\end{array}$ & $\begin{array}{l}\text { Positive } \\
\text { control }\end{array}$ & $\begin{array}{l}\text { Negative } \\
\text { control }\end{array}$ \\
\hline $0.069(-)$ & $0.053(-)$ & $0.044(-)$ \\
\hline
\end{tabular}

Table.2 DAS-ELISA detection for nepoviruses

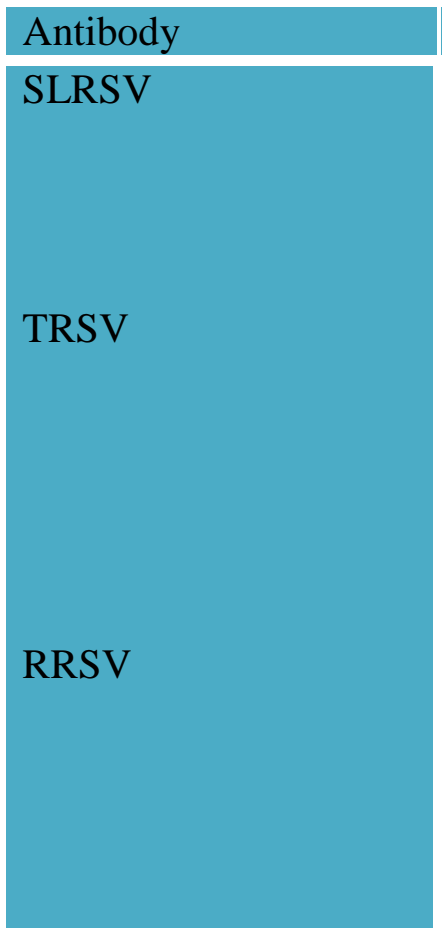

\begin{tabular}{|c|c|c|c|}
\hline Locality & \multicolumn{3}{|c|}{ Mean OD value(at $405 \mathrm{~nm})$} \\
\hline \multirow{4}{*}{$\begin{array}{l}\text { Nauni } \\
\text { Kandaghat } \\
\text { Dhanda }\end{array}$} & $\begin{array}{l}\text { Test } \\
\text { sample }\end{array}$ & $\begin{array}{l}\text { Positive } \\
\text { control }\end{array}$ & $\begin{array}{l}\text { Negative } \\
\text { control }\end{array}$ \\
\hline & $0.206(+)$ & $0.236(+)$ & $0.056(-)$ \\
\hline & $0.632(+)$ & $0.653(+)$ & $0.253(-)$ \\
\hline & $0.346(+)$ & $0.275(+)$ & $0.112(-)$ \\
\hline \multirow{5}{*}{$\begin{array}{l}\text { Nauni } \\
\text { Kandaghat } \\
\text { Dhanda }\end{array}$} & $\begin{array}{l}\text { Test } \\
\text { sample }\end{array}$ & $\begin{array}{l}\text { Positive } \\
\text { control }\end{array}$ & $\begin{array}{l}\begin{array}{l}\text { Negative } \\
\text { control }\end{array} \\
\end{array}$ \\
\hline & $0.244(+)$ & $0.170(+)$ & $0.047(-)$ \\
\hline & $0.580(+)$ & $0.574(+)$ & $0.258(-)$ \\
\hline & $0.376(+)$ & $0.361(+)$ & $0.171(-)$ \\
\hline & $\begin{array}{l}\text { Test } \\
\text { sample }\end{array}$ & $\begin{array}{l}\text { Positive } \\
\text { control }\end{array}$ & $\begin{array}{l}\text { Negative } \\
\text { control }\end{array}$ \\
\hline \multirow{3}{*}{$\begin{array}{l}\text { Nauni } \\
\text { Kandaghat } \\
\text { Dhanda }\end{array}$} & $0.398(+)$ & $0.417(+)$ & $0.046(-)$ \\
\hline & $0.322(+)$ & $0.328(+)$ & $0.037(-)$ \\
\hline & $0.091(-)$ & $0.088(-)$ & $0.064(-)$ \\
\hline
\end{tabular}

Different isolates of strawberry were serologically indexed after visual indexing. Symptoms of mixed infection were exhibited by strawberry plants at all 3 locations thus making it virtually impossible to recognize the virus on the basis of visual indexing. Therefore, ELISA proved to be a handy and reliable tool for proper identification and characterization of these viruses. These studies will help in the production of virus indexed planting material of strawberry which in turn will go a long way for developing a sound certification programme in this commercially important crop. 


\section{Acknowledgment}

The authors sincerely acknowledge the help received from Principal Scientist and Head, KVK Kandaghat and Professor and Head, Department of Plant Pathology, YSPUHF, Nauni for providing the planting material, research facilities and funds for conducting this research.

\section{References}

Anonymous. 2017. $2^{\text {nd }}$ Advance estimate of Area and Production of Horticulture Crops (2016-2017). www.nhb.org [Accessed 12 June 2017]

Belli G, Fortusini A and Vegetti G. 1980. Properties of strain of strawberry latent ringspot virus, associated with a resetting of peach in northern Italy. Acta
Phytopatholgica

Academiae

Scientiarum Hungaricae 15: 113-117.

Clark MF and Adams AN. 1977. Characteristics of the microplate method of enzyme linked immunosorbent assay for the detection of plant viruses. Journal of General Virology 34:475-483.

EPPO/CABI. 1996. Arabis mosaic nepovirus In: Quarantine pests for Europe. $2^{\text {nd }}$ edition (Smith IM, McNamara DG, Scott PR and Holderness M eds). CAB International. Wallingford, U K.

Handa A and Bhardwaj SV.1994. Comparative study of the use of alkaline phosphatase and penicillinase based direct antigen coating ELISA for the detection of a potyvirus from faba bean. FABIS 34: 36-38.

\section{How to cite this article:}

Abhilasha Sharma, Anil Handa, Bunty Shylla, K.K. Pramanick, Shelly Kapoor and Shalini Verma. 2018. Prevalence of Nepoviruses in Strawberry and their Serological Detection. Int.J.Curr.Microbiol.App.Sci. 7(03): 404-409. doi: https://doi.org/10.20546/ijcmas.2018.703.047 